\title{
Evaluation of Immunostimulatory and Antimicrobial Activities of Probiotic Bacteria Isolates from Commercially Available Yoghurts
}

\author{
Angus N Oli*1, Jennifer 0 Aguh ${ }^{1}$, Malachy C Ugwu ${ }^{1}$, Monday Obaji ${ }^{1}$ and Ruth A Afunwa ${ }^{2}$ and \\ Chijioke M Ofomata ${ }^{3}$ \\ ${ }^{1}$ Department of Pharmaceutical Microbiology and Biotechnology, Nnamdi Azikiwe University, Nigeria \\ ${ }^{2}$ Department of Microbiology, Godfrey Okoye University, Nigeria \\ ${ }^{3}$ Department of Clinical Pharmacy and Pharmacy Management, Nnamdi Azikiwe University, Nigeria
}

*Corresponding author: Angus N Oli, Department of Pharmaceutical Microbiology and Biotechnology, Agulu, Nnamdi Azikiwe University, Nigeria.

To Cite This Article: Angus N Oli, Jennifer O Aguh, Malachy C Ugwu, Monday Obaji, Ruth A, Afunwa and Chijioke M Ofomata. Evaluation of Immunostimulatory and Antimicrobial Activities of Probiotic Bacteria Isolates from Commercially Available Yoghurts. Am J Biomed Sci \& Res. 2019 - 5(2). AJBSR.MS.ID.000897. DOI: 10.34297/AJBSR.2019.05.000897.

Received: 眥 September 05, 2019; Published: 䟧 September 17, 2019

\begin{abstract}
Probiotics provide numerous health benefits that transcend basic nutritional requirements of our daily meal. The focus of this study was to evaluate the immunostimulatory capability of probiotic bacteria isolated from commercially available yoghurts in Awka metropolis. Thirty cans of different branded yoghurts were purchased from local supermarkets and prepared using standard procedures. The samples were transferred into De Man, Rogosa and Sharpe (MRS) broth and incubated anaerobically for $24 \mathrm{~h}$. The isolates were identified using biochemical tests. Immunostimulatory activities were evaluated using cyclophosphamide induced immunosuppression and delay hypersensitivity reaction techniques. The antibacterial activity was evaluated using agar diffusion assay. The effects of $\mathrm{pH}$ and temperature on the growth of isolated Lactobacillus spp. as well as their ability to tolerate bile salt were assayed. The immunological study showed that the test isolates were able to significantly boost the white blood cell count, lymphocyte count, neutrophil count, eosinophil count and monocyte count after treatment and induced inflammatory response in the laboratory animals used for the study. All isolated lactobacillus spp. has inhibitory effect on E coli, S aureus and P aeruginosa. Bile salts incorporated in the bacteria cultures were effective on bacterial viability. The probiotic bacteria isolated in commercially available yoghurts have health beneficial effects, which include immunostimulatory and antibacterial activities.
\end{abstract}

Keywords: Probiotics; Immunostimulatory; Yoghurt; Lactobacillus; Nutritional food

\section{Introduction}

Yoghurt which is fermented milk is widely consumed worldwide because of their numerous health benefits [1-3]. Milks are known to contain protein, vitamins, magnesium, potassium and calcium. They play some roles in prevention and treatment of osteoporosis, reduce the risk of high blood pressure, prevent vaginal infection and restore microbiota balance in the gut thereby reducing the risk of gastrointestinal disorder [2]. Outside milk, bacterial culture is one of the major components of yoghurt. These are special strains of bacterial called probiotics because of the numerous health benefits they confer on humans when taken in enough [3-6]. Probiotic bacteria are known to inhibit the growth of dangerous pathogens in the gut, prevent respiratory tract infection in the elderly, children and immunocompromised patients, prevent development and proliferation of monoclonal cells, lower blood cholesterol and boost immune defense against related infectious diseases [7-10].
Though both bacteria and fungi that have beneficial health effects are categorized as probiotics, Lactobacillus spp. have been

well characterized as prominent members of the probiotic group. Studies have reported that several strains of Lactobacillus player a significant role in boosting host immune responses, maintaining the ecosystem of the intestine and inhibiting the growth of several pathogenic bacteria in the gut [11-15]. The ability of probiotics to influence the immune responses of the specialized cells in the body is gaining attention from pharmaceutical and medical researchers $[3,16,17]$. Understanding the mechanisms behind the influence of probiotic on adaptive immunity could open opportunities in prevention medicine $[17,18]$. The focus of this study was to ascertain the presence of probiotic bacteria in commercially available yoghurts in Awka metropolis and to scientifically investigate some of their claimed putative health benefits. 


\section{Materials and methods}

\section{Materials}

Yogurt samples: Thirty (30) samples of yogurt were collected from different areas of Awka city,

Anambra State, Nigeria and transported to Pharmaceutical Microbiology Laboratory, Faculty of Pharmaceutical Sciences of Nnamdi Azikiwe University.

Experimental animals: Eighty (80) albino mice, gender balanced, with weight range 18-25 $\mathrm{g}$ and

age range 4-6 weeks old were used for the study after 14 days acclimatization in standard environmental conditions of relative humidity: $45 \pm 2 \%$, temperature: $26 \pm 2^{\circ} \mathrm{C}$ and natural dark-light cycles. The animals were handled as prescribed by the United States National Research Council Committee [19] for the care and use of lab animals. The study protocols were approved by the Ethics Committee for animal studies of the Faculty of Pharmaceutical Sciences, Nnamdi Azikiwe University Awka Nigeria.

\section{Isolation and identification of microbial isolates}

A volume of $100 \mu \mathrm{l}$ of each sample of yoghurt was transferred into a flask containing MRS Broth (Hi Media Laboratories Pvt. Ltd, Mumbai, India) and incubated at $37^{\circ} \mathrm{C}$ for 24 hours. Thereafter, $100 \mu$ l of the broth samples were spread on MRS agar (Hi Media Laboratories Pvt. Ltd, Mumbai, India) and further incubated at $37^{\circ} \mathrm{C}$ anaerobically for 48 hours. Bacterial cultures were sub-cultured to obtain pure isolates. The isolates were identified using the following biochemical tests: Gram staining, lactose fermentation, Indole test, Catalase test, Coagulase test, Oxidase test, Urease test, Citrate test, Starch hydrolysis and Lysine hydrolysis. The confirmed isolates were stored in anaerobic jar until ready for use.

\section{Evaluation of $0.3 \%$ bile salt tolerance}

Saturated bile solution made from powdered bile extract $(\mathrm{Ox}$ oid) was prepared according to the method described by Chan et al. [20]. The saturated bile salt at $0.3 \%$ concentration was added to an overnight MRS broth culture containing the test isolates. Pour plate counts method using 10 -fold serial dilutions was used to enumerate viable cells of Lactobacillus spp.

\section{Resistance to low $\mathrm{pH}$ (2.5)}

The $\mathrm{pH}$ of an overnight MRS broth culture containing $0.1 \mathrm{~mL}$ of aliquot was adjusted following the procedure described by Desai [21]. Each sample was taken every hour and the viable cells were enumerated using pour plate counts method.

\section{Determination of antibiotic susceptibility profile of test isolates}

Mc Farland 0.5 turbidity standard was used to adjust the inoculate of the Lactobacillus spp. in an overnight culture grown at $37^{\circ} \mathrm{C}$. Disc diffusion susceptibility test described by Cheesbrough was carried out [22]. A sterilized wire loop was used to transfer 3-5 isolated colonies from an MRS plate into a sterile test tube containing physiological saline. The colonies were emulsified in the normal saline to obtain a homogenous suspension of the bacterial cells. The turbidity of the suspension was adjusted visually to that of Mc Farland 0.5 turbidity. A sterile swab stick was dipped in the standardized inoculate and applied to the surface of the Mueller Hinton agar plates. The antibiotic disks (penicillin, rifampicin, amoxicillin, tetracycline and metronidazole) were aseptically placed on the inoculated plates using sterilized forceps to ensure proper contact. Plates were incubated anaerobically at $37^{\circ} \mathrm{C}$ for 24 hours. The plates were observed for possible inhibition zone diameter around the disks.

\section{Determination of antibacterial activity}

Antimicrobial activity of the Lactobacillus spp. was evaluated following agar well diffusion method described by Ghamba et al. [23]. Dilutions of $0.25-1 \mathrm{mg} / \mathrm{mL}$ were prepared from stock solutions of the isolate. A $20 \mathrm{~mL}$ volume of molten Mueller Hinton agar was dispensed into sterile Petri dishes and inoculated with $0.1 \mathrm{~mL}$ fresh cultures of test isolates (Escherichia coli, Staphylococcus aureus, and Pseudomonas aeruginosa) aseptically and allowed to set. Holes of $6 \mathrm{~mm}$ diameter were made in the agar plates using a sterile metal cork-borer. A $60 \mu$ l of the various dilutions of each isolate were dispensed in each hole under aseptic condition. The plates were incubated at $37^{\circ} \mathrm{C}$ for 24 hours.

\section{Immunological studies}

Cyclophosphamide induced immunosuppression studies: This was carried out using the

method described by Ashraf and Shah [24]. A total of 40 albino mice were grouped into 5 with each group having 8 mice. Blood samples were collected from all the animals in the group and were analyzed for total white blood cell count and differential count. These values were termed basal value. The immune system of all the animals was suppressed by single administration of $70 \mathrm{mg} / \mathrm{kg}$ of cyclophosphamide intraperitoneally. The animals were left for 72 hours for proper immune suppression. Blood samples were collected from the animals and was analyzed for the WBC count and differential count for confirmation of suppression. These were termed pre-treatment values. The animals received daily treatments as follows:

Group I received $10 \mathrm{mg} / \mathrm{kg}$ distilled water

Group II received $100 \mathrm{mg} / \mathrm{kg}$ of levamisole

Group III received $0.1 \mathrm{ml}$ brand A yoghurt isolate

Group IV received $0.1 \mathrm{ml}$ brand B yoghurt isolate

Group V received $0.1 \mathrm{ml}$ brand C yoghurt isolate

The animals were treated for 14 days. Their blood samples 
were collected at the end of the treatment to compare the WBC and differential counts.

Cellular immune response/delay type hypersensitivity: Cellular immune response test was

carried out as described by Allen [25]. Forty (40) adult albino mice of both sexes were used. They were grouped into 5 , groups of 8 mice each. The animals were treated for 14 days as follows:

Group I received $10 \mathrm{mg} / \mathrm{kg}$ distilled water

Group II received $100 \mathrm{mg} / \mathrm{kg}$ of levamisole

Group III received $0.1 \mathrm{ml}$ brand A yoghurt isolate

Group IV received $0.1 \mathrm{ml}$ brand B yoghurt isolate

Group V received $0.1 \mathrm{ml}$ brand $\mathrm{C}$ yoghurt isolate

Their paw volume was measured on day 14 and was termed basal. Then the animals were injected with $0.025 \mathrm{ml}$ of 109 sheep red blood cell (SRBC) in the left paw and $0.025 \mathrm{ml}$ of normal saline in the right paw. Twenty-four (24) hours after the injection, the paw volume was again measured. Increase in paw volume was considered an index of cell mediated immunity/ delayed hypersensitivity.

$\%$ Inhibition $=((\Delta y-\Delta x) 100) / \Delta y$.

Where, $\Delta x=$ difference in the treated group and $\Delta y=$ difference in control groups.

\section{Result of Microbial Isolation}

The initial step on isolation and identification of the test isolates was based on the colony morphology. The round creamy colonies of the Lactobacillus spp. on MRS agar were observed as shown in Figure 1.
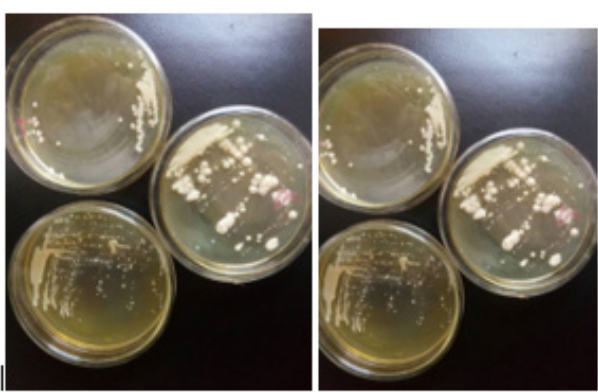

Figure 1: Colonies of Lactobacillus spp on MRS agar.

\section{Biochemical confirmation of the test isolate}

The biochemical tests showed that the test isolates were generally Gram positive, indole negative, oxidase negative, catalase negative and non-motile bacilli. The isolates were able to fermentation glucose, fructose, D-mannitol and sucrose. The antibacterial activity of all the isolated Lactobacillus has inhibitory effect on $\mathrm{E}$ coli, $\mathrm{S}$ aureus and $\mathrm{P}$ aeruginosa while the antibiotic susceptibility test showed that the isolates can grow in the presence of penicillin, rifampicin, amoxicillin and tetracycline. Bile tolerance test revealed that the isolates could also survive bile salt

Tolerance to acid, bile salt and temperature by lactobacilli

At $\mathrm{pH}<3$, the number of bacteria in the medium decreased because of the loss of viability. At $\mathrm{pH} \leq 2.0$, no viable bacterial cells were detected after the first hour suggesting that most isolates were killed by severe $\mathrm{pH}$. Also, all the isolates were able to grow in the presence of bile salt. Though the isolates were able to grow at temperature ranges from $25-40^{\circ} \mathrm{C}$, the optimal growth was observed at $37^{\circ} \mathrm{C}$ (Table 1 ).

Table 1: Effect of $\mathrm{pH}$ and Temperature on the growth of the test isolates.

\begin{tabular}{|c|c|c|c|c|c|c|c|c|c|c|}
\hline pH & 1 & 2 & 3 & 4 & 5 & 5.5 & 6 & 6.5 & 7 & 7.5 \\
\hline Growth & NG & NG & ++ & ++ & +++ & +++ & +++ & +++ & ++ & + \\
\hline $\begin{array}{c}\text { Temp } \\
\text { (oC) }\end{array}$ & 20 & 25 & 30 & 37 & 42 & 45 & & & & \\
\hline Growth & + & + & + & ++ & + & + & & & & \\
\hline
\end{tabular}
no growth

\section{Cyclophosphamide induced immunosuppression}

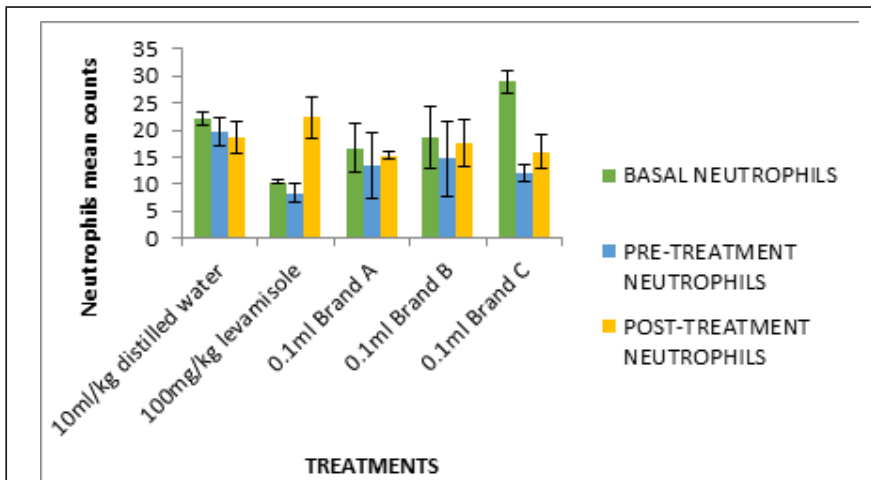

Figure 2: Cyclophosphamide induced immunosuppression of mice fed with test isolates (Neutrophil counts in $\mathrm{mm}^{3}$ ).

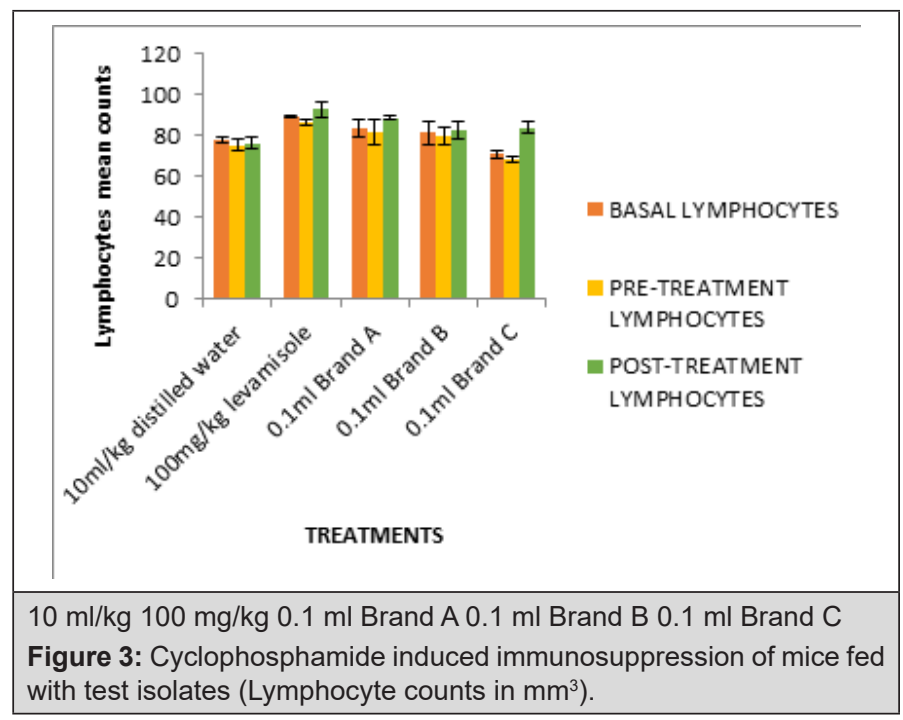

In Figure 2, the white blood cell count after treatment (0.79- 
$0.90 \mathrm{~mm}^{3}$ ) were significantly high compared to negative control $\left(0.5 \mathrm{~mm}^{3}\right)$. Figures 2-6 followed the same pattern with significant increase in lymphocyte count, neutrophil count, eosinophil count and monocyte count after treatment. Figure 7 shows that the test isolates had no effect on the basophil count. This pattern was also observed when the mice were treated with positive control (levamisol) and negative control (distilled water). This could be as a result of absence of basophil in immune responses of the host organism.
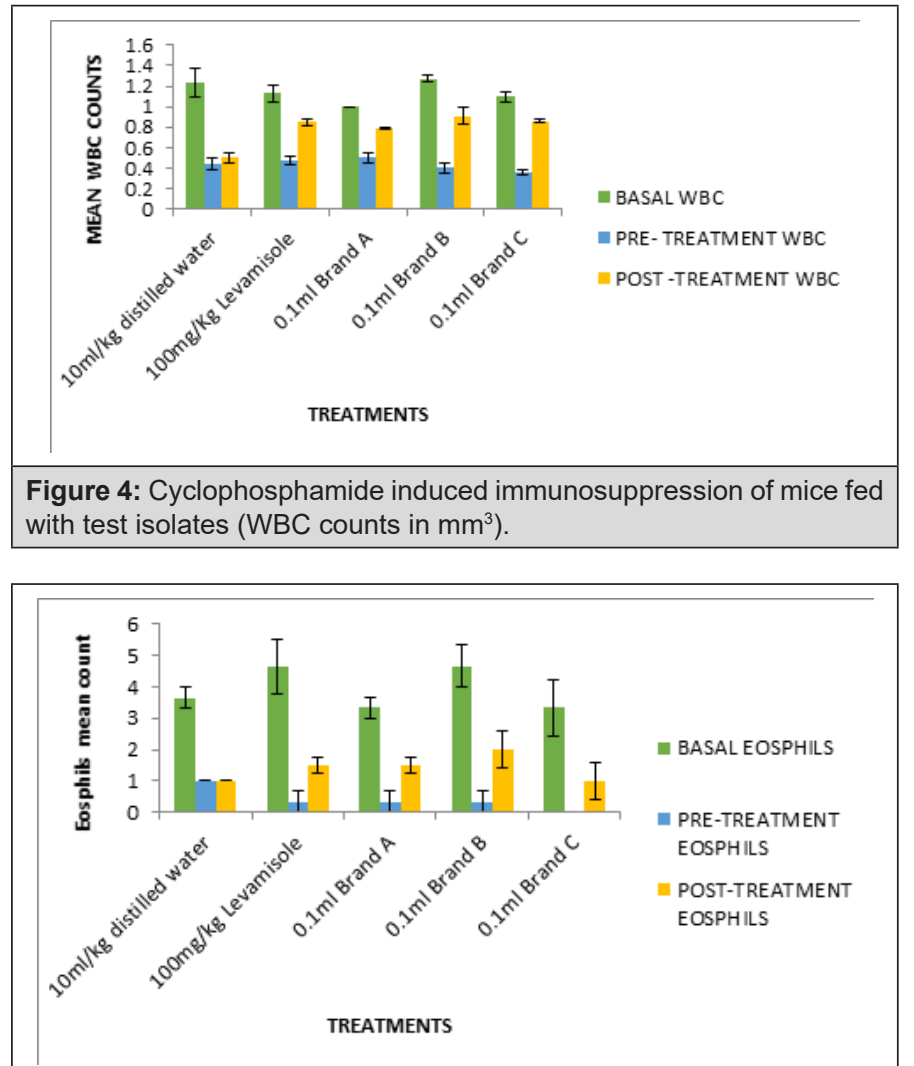

Figure 5: Cyclophosphamide induced immunosuppression of mice fed with test isolates (Eosophil counts in $\mathrm{mm}^{3}$ ).

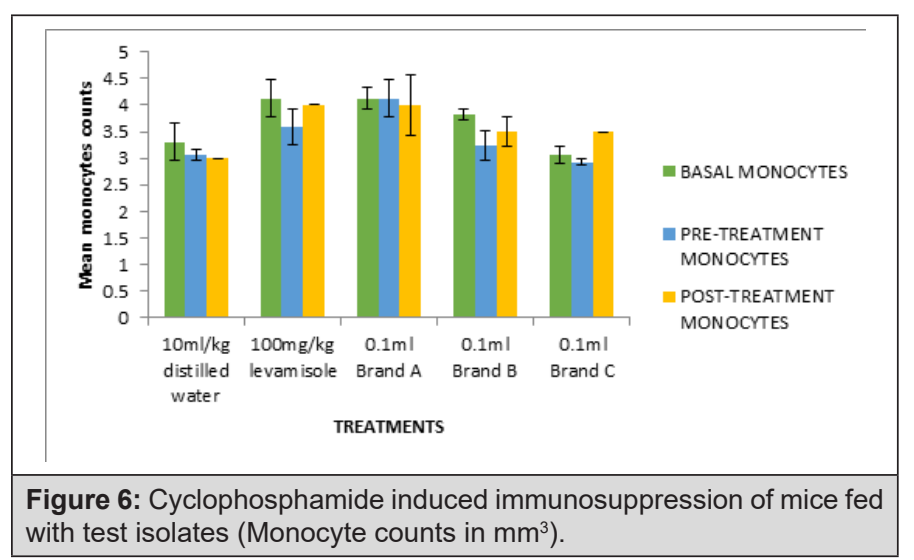

with test isolates (Monocyte counts in $\mathrm{mm}^{3}$ ).

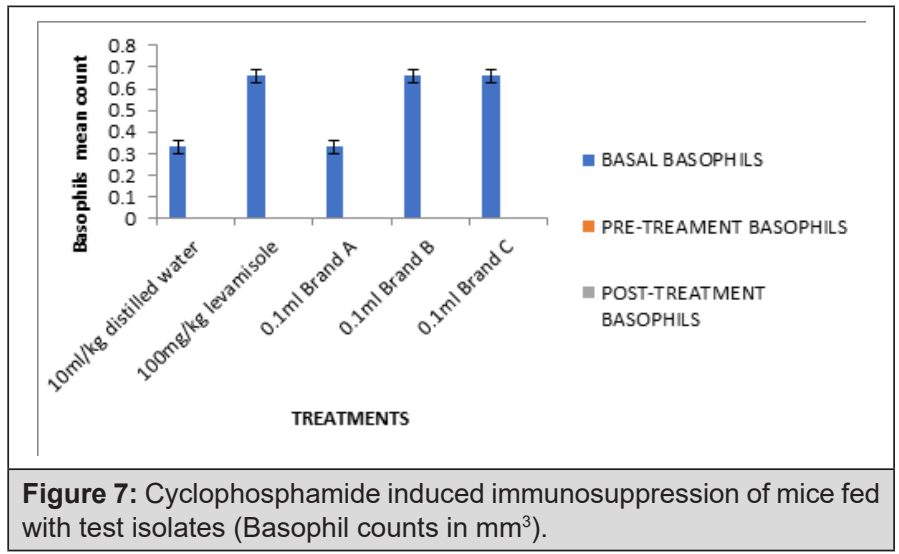

\section{Delay hypersensitivity reaction}

The inflammatory responses were observed on the foot pad of the mice within 24 hours. Figure 8 shows that all the test isolates and the positive control (levamisol) reduced the size of the foot pad of the mice within 24 hours.

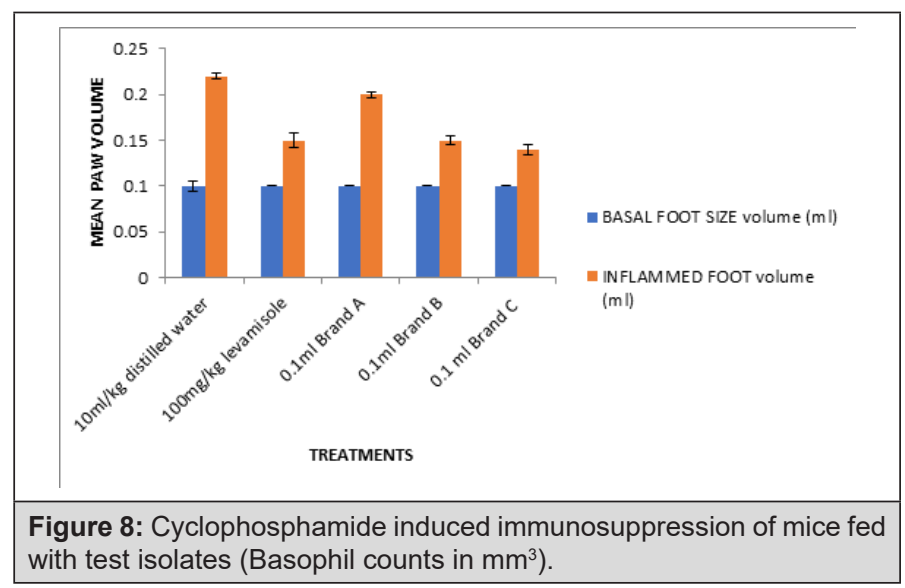

\section{Discussion}

Chan et al reported that acids such as hydrochloric acid ( $\mathrm{HCl}$ ) found also in human stomach, disrupt the biomolecules of cells, such as fatty acids, proteins and DNA [20]. We observed that at low $\mathrm{pH}$ environments $(\mathrm{pH}<3)$, the growth and viability of Lactobacilli isolates were reduced. This is also in line with a previous study which demonstrated that exposing Lactobacillus spp. to gastric acid with $\mathrm{pH} \geq 2$ after 3 hrs. incubation caused a reduction in the viability count of the bacteria intensively [26]. The lactobacillus test isolates showed excellent activity against common clinical pathogens when the antimicrobial susceptibility pattern of the probiotic isolates was evaluated, thereby supporting the reported that some Lactobacillus spp. were able to sufficiently inhibit the growth of some selected clinical pathogens [27]. Other studies showed also that some strains of Lactobacillus spp. had an inhibitory effect on different indicator bacteria [28-30].

There are many strains among lactobacilli with documented probiotic ability, thus they have a more application in prevention of infection [31]. During the evaluation of acid and bile tolerance, the growth abilities of the isolated strains showed that all the isolates 
in this study could not tolerate the $\mathrm{pH} \leq 2$ but could grow in the presence of bile salt. Similar findings were reported previously and showed that the protective effect of food matrix prevents bacteria from bile exposure and hence, gives rise to the increased bile resistance of microbial strains [26]. Acid and bile salt tolerance have been demonstrated as important virulence mechanisms for pathogenic microorganisms [32].

The mechanism of microbial dead after exposure to bile and heat has been linked to the disruptions of cellular homeostasis that causes "the dissociation of lipid bilayer and integral protein of their cell membranes, resulting in bacterial content leakage and finally death of cell" $[33,34]$. The results of this study showed that yoghurt can be consumed as a native reserve for beneficial bacteria such as probiotics, although extra studies should be done for determining the probiotic effects of isolated lactobacilli and other lactic acid bacteria of the yoghurt.

In this study, we found some isolates of Lactobacilli with strong immunostimulatory activities. The result showed that the isolates significantly boosted the immune cells in animal model with depressed immunity. There have been reports that some strains of Lactobacilli used in fermented milk have immunostimulatory activities and can prevent allergic diseases as well as infectious diseases [35-37].

\section{Conclusion}

The study of immunostimulatory activities of commercially available yoghurts in Awka metropolis showed that most of the yoghurts contain viable Lactobacilli capable of boosting immune system and inhibiting the growth of some pathogenic bacteria. The results presented in this study should serve as initial step for further studies that can investigate the mechanisms involved in the immunomodulatory activities of probiotic Lactobacilli. Equally important are approaches in search of safe use of all discovered probiotic strains

\section{Authors' contributions:}

Jennifer O. Aguh did the data acquisition (laboratory investigations); Angus Nnamdi Oli and Monday Obaji participated in manuscript writing, Malachy Ugwu and Angus Nnamdi Oli conceptualized and designed the study, Ruth Afunwa read the manuscript critically for intellectual content while Chijioke Ofomata Maxwell did literature search and gave the very first concept for the study.

\section{References}

1. Daliria Eric Banan Mwine, Lee Byong H (2015) New perspectives on probiotics in health and disease. Food Science and Human Wellness 4(2): 56-65.

2. Wilkins T, Sequoia J (2017) Probiotics for Gastrointestinal Conditions: A Summary of the Evidence. Am Fam Physician 96(3): 170-178.

3. Marco ML, Heeney D, Binda S, Cifelli CJ, Cotter PD, et al. (2017) Health benefits of fermented foods: microbiota and beyond. Curr Opin Biotechnol 44: 94-102.

4. Aureli P, Capurso L, Castellazzi AM, Clerici M, Giovannini M, et al. (2011)
Probiotics and Health: An Evidence-Based Review. Pharmacological Research 63(5): 366-376

5. Kechagia M, Basoulis D, Konstantopoulou S, Dimitriadi D, Gyftopoulou $\mathrm{K}$, et al. (2013) Health benefits of probiotics: a review. ISRN nutrition 2013: 481651.

6. Vandenplas Y, Huys G, Daube G (2015) Probiotics: an update. J Pediatr (Rio J) 91(1): 6-21.

7. Markowiak P, Śliżewska K (2017) Effects of Probiotics, Prebiotics, and Synbiotics on Human Health. Nutrients 9(9): E1021.

8. Amara AA, Shibl A (2015) Role of Probiotics in health improvement, infection control and disease treatment and management. Saudi Pharmaceutical Journal 23(2): 107-114.

9. Yan Fang, Polk DB (2011) Probiotics and immune health. Curr Opin Gastroenterol 27(6): 496-501.

10. Lye Huey Shi, Kunasundari Balakrishnan, Kokila Thiagarajah, Nor Ismaliza Mohd Ismail, Ooi Shao Yin (2016) Beneficial properties of probiotics. Tropical Life Sciences Research 27(2): 73-90.

11. Azad M, Sarker M, Li T, Yin J (2018) Probiotic Species in the Modulation of Gut Microbiota: An Overview. BioMed research international 2018: 9478630 .

12. Nabila Gulzar, Iqra Muqaddas Saleem, Saima Rafiq, Muhammad Nadeem (2019) Therapeutic Potential of Probiotics and Prebiotics [Online First] Intech Open.

13. Arshad F, Mehmood R, Hussain S, Khan MA, Khan MS (2018) Lactobacilli as Probiotics and their Isolation from Different Sources. Br J Res 5(3): 43.

14. Wang Jing, Ji Haifeng, Wang Sixin, Liu Hui, Zhang Wei, et al. (2018) Probiotic Lactobacillus plantarum Promotes Intestinal Barrier Function by Strengthening the Epithelium and Modulating Gut Microbiota. Frontiers in Microbiology 9(1953).

15. Alemayehu Getahun, Anteneh Tesfaye, Diriba Muleta (2017) Investigation of the Potential Benefits and Risks of Probiotics and Prebiotics and their Synergy in Fermented Foods. Singapore Journal of Chemical Biology 6(1): 1-16.

16. Md Abul Kalam Azad, Manobendro Sarker, Dan Wan (2018) Immunomodulatory Effects of Probiotics on Cytokine Profiles. BioMed Research International 2018: 1-10.

17. Bubnov RV, Spivak MY, Lazarenko LM, Bomba A, Boyko NV (2015) Probiotics and immunity: provisional role for personalized diets and disease prevention. The EPMA journal 6(1): 14.

18. Marieta Georgieva, Kaloyan Georgiev, Peter Dobromirov (2015) Probiotics and Immunity. Immunopathology and Immunomodulation, Krassimir Metodiev, Intech Open.

19. National Research Council (US) Committee for the Update of the Guide for the Care and Use of Laboratory Animals (2011) Guide for the Care and Use of Laboratory Animals, $8^{\text {th }}$ edition. National Academies Press, USA

20. Chan HK, Sahadeva RPK, Leong SF (2011) Survival of commercial probiotic strains to $\mathrm{pH}$ and bile. Int Food Res J 18(4): 1515-1522.

21. Desai A (2008) Strain identification, viability and probiotics properties of Lactobacillus Casei. Thesis, school of Biomedical and health sciences. Victoria University, Australia p. 48-53.

22. Cheesbrough M (2006) District Laboratory Practice in Tropical Countries. Part 2, $2^{\text {nd }}$ Edition, Cambri Univer Press, UK 7: 132-234.

23. Ghamba PE, Balla H, Goje LJ, Halida A, Dauda MD (2014) In-vitro antimicrobial activities of Vernonia amygdalina on selected clinical isolates. Int J Cur Microbiol Appl Sci 3(4): 1103-1113.

24. Ashraf R, Shah PN (2011) Selective and Differential Enumerations of Lactobacillus Delbrueckii Subsp. Bulgaricus, Streptococcus Thermophilus, Lactobacillus Acidophilus, Lactobacillus Casei and Bifidobacteri- 
um spp. in yogurt-a review, International journal of food microbiology 149(3): 194-208.

25. Allen IC (2013) Delayed Typed Hypersensitivity Models in Mice. Methods Mol Biol 1031: 101-107.

26. Hassanzadazar H, Ehsani A, Mardani K, Hesari J (2012) Investigation of antibacterial, acid and bile tolerance properties of lactobacilli isolated from Koozeh cheese. Veterinary research forum: an international quarterly journal 3(3): 181-185.

27. Rossi F, Amadoro C, Colavita G (2019) Members of the Lactobacillus Genus Complex (LGC) as Opportunistic Pathogens: A Review. Microorganisms 7(5): 126 .

28. Ren D, Zhu J, Gong S, Liu H, Yu H (2018) Antimicrobial Characteristics of Lactic Acid Bacteria Isolated from Homemade Fermented Foods. BioMed research international 2018: 1-9.

29. Ołdak A, Zielińska D, Rzepkowska A, Kołożyn Krajewska D (2017) Comparison of Antibacterial Activity of Lactobacillus plantarum Strains Isolated from Two Different Kinds of Regional Cheeses from Poland: Oscypek and Korycinski Cheese. BioMed research international 2017: 1-10.

30. Teanpaisan R, Piwat S, Dahlén G (2011) Inhibitory effect of oral Lactobacillus against oral pathogens. Lett Appl Microbiol 53(4): 452-459.

31. Kurniawan I, Simadibrata M (2011) The Role of Probiotics to Improve Gut Health in the Elderly. Med J Indones 20(3): 226-231.
32. Ejiofor OS, Ajunwa OM, Ezeudu CE, Emechebe GO, Okeke KN, et al. (2018) The Bacteriology and Its Virulence Factors in Neonatal Infections: Threats to Child Survival Strategies. Journal of pathogens 2018: $1-11$.

33. Adams CA (2010) The probiotic paradox: live and dead cells are biological response modifiers. Nutr Res Rev 23(1): 37-46.

34. Eurydice Flore Tiepma Ngongang, Bernard Tiencheu, Bertrand Tatsinkou Fossi, Aduni Ufuan Achidi, Dzelafen Marcel Shiynyuy, Hilaire Macaire Womeni, Zambou Ngoufack François (2016) Isolation and Identification of Cholesterol Lowering Probiotic Bacteria from Palm Wine (Raffia mambillensis). Journal of Microbiology Research 6(5): 93-102.

35. Mokoena MP (2017) Lactic Acid Bacteria and Their Bacteriocins: Classification, Biosynthesis and Applications against Uropathogens: A Mini-Review. Molecules (Basel, Switzerland) 22(8): E1255.

36. Ozdemir O (2010) Various effects of different probiotic strains in allergic disorders: an update from laboratory and clinical data. Clinical and experimental immunology 160(3): 295-304.

37. Liévin Le Moal V, Servin AL (2014) Anti-infective activities of lactobacillus strains in the human intestinal microbiota: from probiotics to gastrointestinal anti-infectious bio-therapeutic agents. Clinical microbiology reviews 27(2): 167-199. 